\title{
The influence of Hallyu, packaging and subjective norms towards buying intention on culture adaptation in Etude House
}

\author{
Yuco Aldelina \& Jony Oktavian Haryanto \\ President University, Bekasi, Indonesia
}

\begin{abstract}
The growth of cosmetic's industries became rapid especially in Indonesia with the presence of local brands cosmetics and imported brands cosmetics. One of the competitors is Etude House, imported brand cosmetic from South Korea, which is now demanded by men and women especially the young people. Hence, researcher interested to have the research on The Influence of Hallyu, Packaging and Subjective Norms towards Buying Intention on Culture Adaptation in Etude House. This study used the non-probability sampling with purposive sampling, 200 respondents were taken part, and the data was tested by using structural equation modeling with AMOS2.2. The result of the findings showed that Hallyu had no positive influence on buying intention but had a positive influence on culture adaptation, packaging had a positive influence on buying intention, subjective norm had a positive influence on buying intention and culture adaptation, but buying intention had no positive influence on culture adaptation.
\end{abstract}

Keywords: Hallyu, subjective norms, buying intention, culture adaptation

\section{INTRODUCTION}

Cosmetic industry is one of the industries in the world that is facing a tough and severe competition. According to Indonesia Finance Today (2015), Indonesia's cosmetic market value generated over US\$ 5 billion with the average growth of $12 \%$ per year.

The opportunities of cosmetics market in Indonesia is still very large and cosmetic industry in Indonesia is also a good place for the foreign company to enter the market, it can be seen from the $70 \%$ market share of the cosmetic industry in Indonesia is ruled by the foreign company. One of them is Etude House, a cosmetic product from South Korea with the pink pastel color that gives a girly impression to their consumers to easily attract the women's interest. According to Teen Magazine, Etude House was established in 1966. Then, it changed into Oscar Corporation in 1985. Finally, in 1997 the company name was changed to Etude Corporation then changed to Etude House as today.

The development of the cosmetic products is becoming the trend and basic goods for the people in the developing country like Indonesia. It can be seen not only from the number of the outlets that sell the cosmetic products, starting from the big to small outlet, but also from the way the cosmetics used to.
Nowadays, several men or women are using cosmetics in their activities. The trend of the cosmetic industry for the men and women especially teenagers and young adults is the products from South Korea. This caused by the K-pop fever in Indonesia featured by the beautiful actress, actors, and promotion of their cosmetic products. The activity to spread out their culture and products, called as "Hallyu" or the "Korean Wave".

Buying intention or purchase intention is the willingness of a customer to buy a certain product and the factors of buying intention come from external and internal sides. From many cosmetic products that are offered in the market, consumers usually use a specific factor to create the buying intention of a product such as trends, packaging, and subjective norm. Trends such as Hallyu could trigger the fans to buy, emulate and use the same product to be like actress and actors from South Korea.

Attractive packaging will affect the buying intention, which is in line with the theory of consumer behavior psychologically saying that a consumer will make observations of the goods to be purchased and used by consumers (Kotler \& Keller 2014). Attractive product packaging will encourage a consumer to provide ease of use and storage so that consumers feel satisfied. The unique design, an 
assortment of sizes, colors, forms, and information given on the packaging will increasingly influence consumers in determining the choice of products. Etude House's packaging is very attractive as it used the pink pastel color, good material, and design.

Product quality is one of the factors that triggers the buying intention, the better the quality, the greater the potential. However, the subjective norm can reverse the fact that better quality will increase the buying intention. This caused by a subjective norm which is a component contains the decision made by an individual after considering the views of those people who influence the behavior. Family, friends, and people who have higher positions such as teachers, lecturers, superiors, and those who have the dominant role in one's life to make a positive contribution to consumer buying interest.

Based on the background, the objective of this research is to determine how much the influence of Hallyu, packaging, and subjective norm on consumer buying intention and how much the influence of Hallyu, subjective norm, and buying intention on the cultural adaptation will be the main research problems of this research. The benefit of this research will be addressed to the company as input in developing consumer buying intention and other parties as additional knowledge or concept, particularly on Hallyu, packaging, subjective norm, buying intention, and cultural adaptation.

Based on the description above, this study will examine matters related to the buying intention, which includes: Hallyu, packaging, subjective norm, and the role of Hallyu, subjective norm, and buying intention towards culture adaptation. As for the research question of this study are as follows: 1. Does Hallyu influence Etude House's consumer buying intention? 2. Does packaging influence Etude House's consumer buying intention? 3. Does subjective norm influence Etude House's consumer buying intention? 4 . Does buying intention influence culture adaptation on Etude House? 5. Does Hallyu influence culture adaptation on Etude House? And 6. Does subjective norm influence culture adaptation on Etude House?

\section{RESEARCH METHODS}

The subjects of this research were women who had been buying or consuming the Etude House. The data to be used were the primary data, collected by distributing the questionnaires in person and via online by the Google Docs. The research population was the people who live in Bekasi and use the Etude House's product. The sample of this research was students, employees, housewives, and others who live in Bekasi area. Nonprobability sampling - the judgmental sampling was used in this study. According to Copper \& Schindler (2011), judgmental sampling is a sampling technique with certain considerations. In this study, respondents selected were respondents who met the following criteria: 1) Male or Female aged 17 - 40 years. 2) Have used the Etude House's product. The number of samples taken was 200 respondents from several groups, such as students, employees, entrepreneurs, and housewives who've bought Etude House's products. The primary data comes from the original source by its own question. The questionnaire contains about four variables, Hallyu, packaging, subjective norms, and cultural adaptation.

This research used Structural Equation Modeling (SEM) methods. Questionnaire instrument used was a 5-point Likert Scale, with the interval level of measurements as follows: (1) Strongly disagree, (2) Disagree, (3) Neither agree or disagree, (4) Agree, and (5) Strongly Agree. The author has conducted pre-test questionnaire to 30 respondents to see the validity and reliability of each of the indicators that will be used as a statement in the questionnaire. According to Hair et al., (2010), an indicator is declared valid if the value if corrected item-total correlation $\geq 0.361$ and declared reliable if the value of Cronbach's Alpha $>0.7$. The data obtained from the questionnaires were analyzed using Structural Equation Modeling method with AMOS 2.2.

\section{DISCUSSIONS}

By using SEM and AMOS 2.2, it is obtained overall suitability structural model test, which also produces the conformity value or GOF. Conformity values are shown in table 1. Good-of-Fit criteria are the step in which the model is concluded as acceptable or not. The Chi-Square indicates the difference between the estimated population covariance and sample covariance. The smaller Chi-square value, the better. CMIN/DF was done in order to find the minimum standard of discrepancy function divided by the degree of freedom. As the CMIN/DF value is 2.693, which passes the requirement to the Good-ofFit criteria, thus it can be concluded that the model is acceptable. RMSEA is measuring how well the model with the parameter of the population, since RMSEA value ranging from $\leq 0.08$, it indicates mediocre fit, therefore as the RMSEA value in this research is .092, this model is considerably mediocre fit in the population. TLI or Tucker-Lewis Index is a measurement used to compare the proposed model and the possible alternative model. As the TLI value in this research is .809 , the model is concluded as 
acceptable fit. IFI or Incremental Fit Index is a measurement used to measure the proposed model whether it is correct or not. As the IFI value in this research is .845 , this model is concluded as acceptable fit. The CFI or Comparative Fit Index measurement is used to measure the improvement in noncentrality in going off the model. Since this research shows the value of .0842 , thus it is considered as a good fit model. After analyzing the assessment from the model fit index, it is concluded that the model is acceptable in the population and has a mediocre fit to reach the reasonable level in real life application.

Table 1. Goodness of Fit (GOF) Value Index

\begin{tabular}{|c|c|c|c|}
\hline GOF Indicator & Good Fit Value & $\begin{array}{l}\text { Estima- } \\
\text { tion Re- } \\
\text { sult }\end{array}$ & Conclusion \\
\hline $\begin{array}{l}\mathrm{X}^{2}-\text { Chi } \\
\text { Square }\end{array}$ & $\mathrm{P}<0.05$ & .000 & Significant \\
\hline CMIN/DF & $\mathrm{L} 0<\mathrm{CMIN} / \mathrm{DF}<3$ & 2.693 & Good Fit \\
\hline RMSEA & $\mathrm{RMSEA} \leq 0.08$ & 0.092 & $\begin{array}{l}\text { Mediocre } \\
\text { Fit }\end{array}$ \\
\hline TLI & $0.0<\mathrm{TLI}<0.9$ & .809 & Good Fit \\
\hline IFI & $\mathrm{IFI} \geq 0.90$ & .845 & $\begin{array}{l}\text { Marginal } \\
\text { Fit }\end{array}$ \\
\hline CFI & $0.8<\mathrm{CFI}<0.9$ & .842 & Good Fit \\
\hline
\end{tabular}

Source: Tasmin and Woods (2010), Arbuckle (2012), Primary

Data (2016)

Table 2 shows the aspects that affect the buying intention and culture adaptation most. The most influential in buying intention is the $\mathrm{H} 2$ or the packaging to buying intention and the most influential in a cultural adaptation that is the $\mathrm{H} 6$ or subjective norms to cultural adaptation. P-value shows the significant level of the variable. Therefore, P-value is used to do the hypothesis testing, when $\mathrm{P}$ value is lower than (<) 0.05 , it means significant and the hypothesis is supported by the data.

Table 2. Hypothesis Test

\begin{tabular}{cccc}
\hline Hypothesis & CR & P Value & Findings \\
\hline H1 & 1.906 & .057 & Not supported \\
H2 & 4.304 & .000 & Supported \\
H3 & 2.420 & .016 & Supported \\
H4 & 1.704 & .088 & Not supported \\
H5 & 4.318 & .000 & Supported \\
H6 & 5.913 & .000 & Supported \\
\hline
\end{tabular}

Source: Primary Data (2016)

Based on $\mathrm{H} 1$ on the findings in table 2, P-value is .057 which is more than 0.05 , means the hypothesis is not significant. Hence, the hypothesis of Hallyu has a positive influence on consumer buying intention is not supported by data. These findings are not in line with Rizki (2014) who stated that Hallyu makes the Korean product on the market as the targets for the must-buy-items to follow the Korean artist. The hypothesis is rejected, allegedly, because of the people appreciate the Korean drama, music and culture, but the buying intention on the Korean product is still questionable. The respondents also are not interested in buying the products from South Korea even there's the Hallyu effect. The respondents only got the message of Hallyu as the cultural aspects such as the language, TV shows, music, fashion, and foods.

Based on the findings in table 2, The P-value of $\mathrm{H} 2$ is 0.000 . In other words, it is below than 0.05 and the $\mathrm{H} 2$ is significant. Hence, the hypothesis of packaging has a positive influence on consumer buying intention is supported by the data and hypothesis is accepted 2. These findings are in line with the statement of Chandrawati (2015) that a good packaging will attract consumer because of its color, font, background, and the shape of packaging. Therefore, a better packaging will affect the consumer purchasing intention. Currently, the role of packaging change with increasing consumer interest and it becomes a tool used by companies to increase sales and reduce promotion costs. Attributes in packaging such as color, background, shape, text, and so forth can attract the attention of consumers. When consumers are attracted to the packaging then they will buy. But if the packaging does not attract the attention of consumers, the consumer will less likely buy the products. These findings are also in line with Nazarullah (2014) who state that the appeal of the packaging is very important to capture consumer stimulus delivered to manufacturers that trigger their buying interest of consumers.

Based on the findings in table 2 , the $\mathrm{P}$ value of $\mathrm{H} 3$ is .016 which is significant because the $\mathrm{P}$ Value is $<0.05$. Hence, the hypothesis of subjective norms has a positive influence on consumer buying intention is supported by the data and accept H3. These findings are in line with Tjahjono \& Ardi (2008) who stated that subjective norms are form of normative beliefs and willingness to obey the wishes of others that are considered more important and regarding the condition of the importance of the individual or group referents will agree or disagree with the particular behavior. Subjective norms tend to give the indirect pressure to a people to agree and follow the specific action even on a buying action. These findings also in line with Yogatama (2013) who stated that subjective norm also gives the influence and encourage the consumer to the buying intention because of the social pressure felt by individuals to do any action.

Based on the findings in table 2, the P-value of $\mathrm{H} 4$ is .088, means the hypothesis is not significant 
because the $\mathrm{P}$ value is $<0.05$. Hence, the hypothesis of buying intention has a positive influence on culture adaptation is not supported by data. These findings are not in line with Suryanto (2013) who stated that a behavior of purchasing a certain product in a specific place will automatically create a sense of love to the product origin. The hypothesis is rejected, allegedly, because of the Etude House only sells the cosmetic products and they didn't educate the buyer to like and adapt the Korean culture.

Based on the findings in table 2, the P-value of $\mathrm{H} 5$ is 0.000 , means the hypothesis is significant because the $\mathrm{P}$-value is $<0.05$. Hence the hypothesis Hallyu has a positive influence on culture adaptation is supported by the data and accepted. These findings are in line with Farrar (2010) who stated that the purpose of spreading the Hallyu is to create the mindset of the people aboard to like and love the Korean culture. Hallyu has successfully created the mindset of the young people in Indonesia to like and love the Korean Culture. It can be seen from the behavior of the respondents who tend to learn the Korean culture such as language and use the Korean products. Moreover, in the society, it can be seen that K-drama, K-music, and K-fashion are the new trends and culture amongst the people.

Based on the findings in table 2, The P-value of $\mathrm{H} 6$ is 0.000 , in other words, it is $<0.05$ and the H6 is significant. Hence, the hypothesis of the subjective norm has a positive influence on culture adaptation. Subjective norm also successfully creates the mindset of the Indonesian people to like and love the Korean culture. It happens because the subjective norm is the social pressure to make the people follow and believe in someone's perception. These findings are in line with Ajzen (1991) who stated that subjective norm is related to the perceived social influences/pressures to indulge or not to indulge in a given behavior.

\section{CONCLUSIONS}

Thus, it is concluded that (1) Hallyu has no significant and positive influence on consumer buying intention. This statement can happen because of the society tends to absorb and respond well to the spreading Korean culture such as the K-drama, Kmusic, K-fashion, and so forth. The society does not care about the Korean products that are affected by the Hallyu or trends that are booming nowadays. It also happened because of Hallyu cannot guarantee the product quality of the product itself. (2) Packaging has a significant and positive influence on consumer buying intention. This means that the more unique and memorable the product packaging, the greater the consumers buying intention towards the product. (3) Subjective norms have a significant and positive influence on consumer buying intention which signifies that the social pressure can affect the belief of an individual to follow and perform a certain behavior. (4) Buying intention has no significant and positive influence on culture adaptation. This means by purchasing a product from a particular country, it does not mean that people will absorb their culture. (5) Hallyu has a significant and positive influence on culture adaptation. This means the spreading of Hallyu by the TV shows, music, and fashion will trigger the people to like, love, and learn the Korean culture. (6) Subjective norms have a significant and positive influence on culture adaptation. This means that social pressure can affect the people who previously do not like the Korean culture to like the Korean culture. It happens because the subjective norm is a form of normative beliefs and willingness to obey the wishes of others.

There are some limitations of this research as follows: (1) Etude House is the only product which been observed, so there is no comparison with the other product. (2) This research was only done in a small city of Bekasi, so the rearchers hope the future research can be done in a bigger city. (3) Researchers only analyzed the factors of buying intention towards culture adaptation. The variables used in this research were Hallyu, packaging, and subjective norms. Researchers hope in the future research, it can add some variables either on intervening variables, dependent variables or independent variables in order to give new facts which could be used and studied for people and society, such as, advertisement, word-of-mouth, customer satisfaction, loyalty, brand ambassador, and promotion.

\section{REFERENCES}

Ajzen, I. 1991. The theory of planned behavior. Organizational Behavior and Human Decision Processes 50(2): 179-211

Chandrawati, L. 2015. Influence of Price, Pakcaging and Product Quality Towards Purchase Decisions. International Journal of Consumer Studies 7(1): 07-59. doi:10.1108/1061041024916437

Cooper, D.R. \& Schindler, P.S. 2011. Business research methods (11th ed.). New York: Mc GrawHill/Irwin.

Farrar., L. 2010. Korean Wave of culture sweeps across Asia. CNN Turner Broadcasting System.

Kotler, P. \& Keller, K.L. 2014. Marketing Management. 14 Edition. NewJersey : Pearson Education, Inc

Tjahjono, HK. \& Ardi, H. 2008. Kajian Niat Mahasiswa Manajemen UMY Menjadi Wirausaha. Jurnal Utilitas 16(1): 46-63.

Nazarullah, R. 2014. Influence of Packaging towards purchase Intention of Souvernir in Singapore. (Online). (http://etd.unsyiah.ac.id/baca/index.php?id=3290\&page=7). Retrieved December 19, 2016. 
Yogatama, L. 2013. Analisis pengaruh attitude, subjective norm, dan perceived behavior control terhadap intensi penggunaan helm saat mengendarai motor pada remaja dan dewasa muda di Jakarta Selatan. Proceeding PESAT (Psikologi, Ekonomi, Sastra, Arsitektur \& Telmik Sipil) 5. 